\title{
TOCOPHEROL AND FATTY ACIDS CONTENT AND PROXIMAL COMPOSITION OF FOUR AVOCADO CULTIVARS (PERSEA AMERICANA MILL)
}

\author{
D.A.V. Amado ${ }^{a *}$, A.M. Detoni ${ }^{b}$, S.L.C. De Carvalho ${ }^{c}$, A.S. Torquato ${ }^{d}$, C.A. Martin ${ }^{a}$, \\ T.S. TiUman ${ }^{\mathrm{a}}$, C.M. Aguiar a and S.M. Cottica ${ }^{\mathrm{a}}$

\begin{abstract}
${ }^{a}$ Department of Chemical Processes, Federal Technological University of Paraná, 19 Cristo Rei Street, Zip Code 85902-490, Toledo, Paraná. Brazil.

${ }^{\mathrm{b}}$ Agronomic Institute of Paraná - IAPAR, Santa Tereza do Oeste Experimental Station, Highway PRT 163, km 188, Zip Code 85825 000, Santa Tereza do Oeste, Paraná. Brazil.

${ }^{\mathrm{c}}$ Agronomic Institute of Paraná - IAPAR, Londrina Experimental Station, Highway Celso Garcia Cid, km 375, Zip Code 86047 902, Londrina, Paraná. Brazil.

${ }^{\mathrm{d}}$ Federal Technological University of Paraná, 4232 Brazil Avenue, Zip Code 85884-000, Medianeira, Paraná.
\end{abstract} \\ Brazil.
}

(Received: 10 October 2017; accepted: 22 June 2018)

Avocado pulp is widely regarded as a great source of edible oil containing fat-soluble vitamins and omega- 3 fatty acids (FA). However, avocado peel and seeds are also good sources of edible oil and are less explored byproducts. This paper aimed at determining the proximal composition, FA and tocopherol contents of the pulp, peel, and seeds of Quintal, Fortuna, Margarida, and Hass avocado cultivars. The pulps presented high concentrations of oleic acid. In addition, peel and seeds presented lower omega-6/omega- 3 ratios than the pulp. There was also a considerable amount of tocopherol in the peel and seeds, especially in Hass peel $(230.7 \mathrm{mg} / 100 \mathrm{~g})$. According to the results, the peel and seeds of avocado that are considered byproducts, can be utilized in food industry.

Keywords: avocado oil, fruit, lipids, vitamin E, omega-3

Avocado has a high nutritional value with a high content of unsaturated fatty acids, fatsoluble vitamins such as vitamin E, vitamin B6, $\beta$-carotene, fibre, protein, and potassium (Gómez-López, 1998; Honarbakhsh \& Schachter, 2009). Avocado oil has significant levels of omega-6 and omega-9 fatty acids (FA) that provide health benefits for consumers, reducing levels of total cholesterol, triacylglycerol, and LDL-cholesterol, preserving high-density lipoprotein plasma HDL-cholesterol (VILLA-RodríGUEZ et al., 2011).

Main studies have been carried out with avocado regarding pulp oil, with few studies referring to oil extracted from the peel and seed, which are considered byproducts in the avocado industry and represent a significant part of the fruit (DUARTE et al., 2016).

In addition, moisture, ash, and protein contents are also important indices assessed in food, especially in fruit. Moisture, for example, is a good indicator of their commercial value, once it reflects the solid contents and can be used to assess their perishability (VINHA et al., 2013).

In the light of the aforementioned considerations, this paper aimed at determining the proximal composition, FA content, and tocopherols of the peel, pulp, and seeds of four avocado cultivars (Quintal, Hass, Margarida, and Fortuna).

\footnotetext{
* To whom correspondence should be addressed.

Phone: +55 45 3379-6870; e-mail address: daienivieira@hotmail.com
} 


\section{Materials and methods}

\subsection{Sampling}

Four avocado cultivars from 2015 harvest were studied (Quintal, Hass, Margarida, and Fortuna), grown and harvested by the Agronomic Institute of Paraná (IAPAR) in Santa Helena and Londrina, Paraná, Brazil. Ten avocados of each cultivar were used. All samples were initially washed with tap water and then with triple-distilled water. The peel, pulp, and seeds were then carefully separated and homogenized. Different parts of each cultivar were weighed, packed into polyethylene vacuum bags, stored at $-18{ }^{\circ} \mathrm{C}$, and protected from light until the time of analysis.

\subsection{Reagents and standards}

Fatty acid methyl ester standard (mixture 189-19), tricosanoic fatty acid methyl ester (23:0), and alpha, gamma and delta tocopherols were purchased from Sigma-Aldrich. Methanol and isopropanol (HPLC grade) were obtained from Vetec and other chemicals were of analytical grade.

\subsection{Proximate composition}

Moisture, ash, and protein contents were determined in triplicate in accordance with AOAC (1998). Total lipids were extracted by the BLIGH and Dyer (1959) method. The results were expressed as mass percentage (\%) of peel, pulp, or seed.

\subsection{Fatty acids}

Fatty acid methyl esters (FAME) were prepared by methylation of total lipids as described by HARTMAN and LAGO (1973). Methyl esters were separated by gas chromatography (Perkin Elmer, USA) equipped with automatic sampler, flame ionization detector, and Select Fame CP 7420 fused silica capillary column $(100 \mathrm{~m} \times 0.25 \mathrm{~mm}$ i.d. and $0.25 \mu \mathrm{m}$ film thickness $)$. The gas flows were $1.1 \mathrm{ml} \mathrm{min}^{-1}$ for the carrier gas (H2), 40 and $400 \mathrm{ml} \mathrm{min}^{-1}$ for the detector gases, hydrogen and synthetic air, respectively.

The column was heated to $80{ }^{\circ} \mathrm{C}$ in $1 \mathrm{~min}$ and then the temperature was raised to $160{ }^{\circ} \mathrm{C}$ at $20^{\circ} \mathrm{C} \mathrm{min}-1$, followed by an increase of $1{ }^{\circ} \mathrm{C} \mathrm{min}-1$ until reaching $198{ }^{\circ} \mathrm{C}$, increased at a rate of $5{ }^{\circ} \mathrm{C} \mathrm{min}{ }^{-1}$ until reaching $250{ }^{\circ} \mathrm{C}$, remaining for $1.6 \mathrm{~min}$. The total run time was $52 \mathrm{~min}$ and the volume of sample injected was $2 \mu \mathrm{l}$.

Concentrations of FA were determined through Eq. 1, according to VisentAINER (2012). The results were expressed as mg FA per gram of total lipids (TL) and converted to mg FA/100 g sample. Fatty acid analyses were performed in triplicate.

$$
\mathrm{FA}\left(\mathrm{mg} \mathrm{g}^{-1} \text { of TL }\right)=\mathrm{A}_{\mathrm{X}} \times \mathrm{W}_{\mathrm{IS}} \times \mathrm{CF}_{\mathrm{X}} \times 100 / \mathrm{A}_{\mathrm{IS}} \times \mathrm{W}_{\mathrm{X}} \times \mathrm{CF}_{\mathrm{AE}}
$$

where $A_{X}$ is the peak area (fatty acids), $A_{I S}$ is the peak area of the internal standard (IS), $W_{I S}$ is the IS weight added to the sample (in $\mathrm{mg}$ ), $\mathrm{W}_{\mathrm{X}}$ is the sample weight (in $\mathrm{mg}$ ), $\mathrm{CF}_{\mathrm{X}}$ is the theoretical correction factor, and $\mathrm{CF}_{\mathrm{AE}}$ is the factor for conversion of FAMEs to their corresponding fatty acids. 


\subsection{Tocopherol contents}

Alpha, beta, gamma, and delta tocopherols were determined according to FreITAS and coworkers' methodology (2008). The analysis was performed in triplicate at room temperature on a Dionex UltiMate 3000 high efficiency liquid chromatograph with UV/VIS detector (Thermo Scientific, Waltham, USA). The column was C18 (125 $\mathrm{mm} \times 4.0 \mathrm{~mm})$ with a particle diameter of $5 \mu \mathrm{m}$ (Nano Separation Technologies, NST). Loop of $20 \mu \mathrm{l}$ was used, and mobile phase composed of methanol:water $(96: 4 \mathrm{v} / \mathrm{v})$, with a flow rate of $1 \mathrm{ml} \mathrm{min}^{-1}$, was used in the isocratic mode. The wavelength was $292 \mathrm{~nm}$ and quantification was via external calibration with standard curve from stock solutions of alpha, gamma, and delta tocopherol standards with concentrations of 0.5 to $20 \mathrm{mg} \mathrm{l}^{-1}$.

\subsection{Statistical analysis}

The results were submitted to variance analysis (ANOVA) and Tukey's test (5\% probability) using the Agricolae package of R software (R CORE TEAm, 2016).

\section{Results and discussion}

\subsection{Proximate composition}

Margarida cultivar had a higher percentage of pulp (81.0\%) and a lower percentage of seed $(10.5 \%)$ (Table 1$)$. The value obtained for peel percentage $(8.5 \%)$ was close to the values found for Quintal $(7.5 \%)$ and Fortuna $(8.2 \%)$ cultivars $(\mathrm{P}>0.05)$. On the other hand, the fruit of Hass cultivar, which has the lowest weight, presented the highest proportions of peel $(12.9 \%)$ and seed $(29.5 \%)$, which represents around $43 \%$ of fresh fruit residues.

Table 1. Weight and proportion of the peel, pulp, and seeds of four avocado cultivars

\begin{tabular}{lcccc}
\hline & Hass & Quintal & Fortuna & Margarida \\
\hline Whole fruit(g) & $197.65 \pm 2.58^{\mathrm{c}}$ & $571.39 \pm 46.05^{\mathrm{b}}$ & $690.24 \pm 114.72^{\mathrm{ab}}$ & $785.69 \pm 109.97^{\mathrm{a}}$ \\
Peel (\%) & $12.89 \pm 1.06^{\mathrm{a}}$ & $7.46 \pm 0.56^{\mathrm{b}}$ & $8.16 \pm 1.34^{\mathrm{b}}$ & $8.45 \pm 0.38^{\mathrm{b}}$ \\
Pulp (\%) & $57.63 \pm 2.17^{\mathrm{c}}$ & $75.36 \pm 1.63^{\mathrm{b}}$ & $74.68 \pm 3.85^{\mathrm{b}}$ & $81.03 \pm 1.93^{\mathrm{a}}$ \\
Seed (\%) & $29.48 \pm 2.08^{\mathrm{a}}$ & $17.18 \pm 1.00^{\mathrm{b}}$ & $17.16 \pm 2.57^{\mathrm{b}}$ & $10.52 \pm 1.68^{\mathrm{c}}$ \\
\hline
\end{tabular}

Mean \pm standard deviation. The data is the average of 10 fruits for each cultivar. Values followed by different letters in the same line are significantly different $(\mathrm{P}<0.05)$ by Tukey's test

Hass pulp was the one with the lowest moisture value (Table 2) and the highest ash content (1.7\%). The highest level observed for protein was for Margarida seed $(4.0 \%)$ and Quintal peel (3.7\%) (Table 2). Avocado pulps showed the lowest protein values.

Highest values of lipid contents were observed for pulps (13.3 up to $23.4 \%$ ), especially for Quintal pulp, followed by peels. The only exception was for Quintal avocado that showed a higher level of lipid for seed instead of peel.

According to some authors, the lipid content of the fruit indicates its potential as an edible oil source (GómEz-LóPEz, 2002; TANGO et al., 2004). 
Table 2. Proximate composition of different parts of four avocado cultivars

\begin{tabular}{|c|c|c|c|c|c|c|}
\hline & \multicolumn{3}{|c|}{ Moisture (\%) } & \multicolumn{3}{|c|}{ Ash (\%) } \\
\hline & Peel & Pulp & Seed & Peel & Pulp & Seed \\
\hline Hass & $65.38 \pm 0.37^{\mathrm{Bb}}$ & $68.16 \pm 0.68^{\mathrm{Ad}}$ & $49.81 \pm 0.17^{\mathrm{Cd}}$ & $0.87 \pm 0.03^{\mathrm{Ba}}$ & $1.69 \pm 0.22^{\mathrm{Aa}}$ & $0.89 \pm 0.04^{\mathrm{Ba}}$ \\
\hline Quintal & $62.53 \pm 0.23^{\mathrm{Cc}}$ & $72.98 \pm 0.31^{\mathrm{Ac}}$ & $68.24 \pm 0.22^{\mathrm{Ba}}$ & $0.91 \pm 0.03^{\mathrm{Aa}}$ & $0.51 \pm 0.11^{\mathrm{Bb}}$ & $0.82 \pm 0.08^{\mathrm{Aa}}$ \\
\hline Fortuna & $64.86 \pm 0.27^{\mathrm{Bb}}$ & $75.37 \pm 0.38^{\mathrm{Ab}}$ & $62.60 \pm 0.27^{\mathrm{Cb}}$ & $0.35 \pm 0.05^{\mathrm{Bc}}$ & $0.66 \pm 0.03^{\mathrm{Ab}}$ & $0.41 \pm 0.01^{\mathrm{Bc}}$ \\
\hline \multirow[t]{3}{*}{ Margarida } & $69.06 \pm 0.91^{\mathrm{Ba}}$ & $79.23 \pm 0.61^{\mathrm{Aa}}$ & $54.35 \pm 0.15^{\mathrm{Cc}}$ & $0.65 \pm 0.07^{\mathrm{Ab}}$ & $0.76 \pm 0.05^{\mathrm{Ab}}$ & $0.68 \pm 0.02^{\mathrm{Ab}}$ \\
\hline & \multicolumn{3}{|c|}{ Protein $(\%)$} & \multicolumn{3}{|c|}{ Lipid (\%) } \\
\hline & Peel & Pulp & Seed & Peel & Pulp & Seed \\
\hline Hass & $2.71 \pm 0.15^{\mathrm{Ab}}$ & $2.08 \pm 0.41^{\mathrm{Aa}}$ & $2.48 \pm 0.24^{\mathrm{Ab}}$ & $5.67 \pm 0.29^{\mathrm{Bb}}$ & $14.12 \pm 0.06^{\mathrm{Ab}}$ & $2.26 \pm 0.07^{\mathrm{Cc}}$ \\
\hline Quintal & $3.67 \pm 0.44^{\mathrm{Aa}}$ & $1.69 \pm 0.19^{\mathrm{Ca}}$ & $2.84 \pm 0.27^{\mathrm{Bb}}$ & $3.30 \pm 0.20^{\mathrm{Cc}}$ & $23.44 \pm 0.45^{\mathrm{Aa}}$ & $5.33 \pm 0.37^{\mathrm{Ba}}$ \\
\hline Fortuna & $2.36 \pm 0.20^{\mathrm{Ab}}$ & $1.51 \pm 0.12^{\mathrm{Ba}}$ & $2.72 \pm 0.29^{\mathrm{Ab}}$ & $5.39 \pm 0.20^{\mathrm{Bb}}$ & $13.26 \pm 0.17^{\mathrm{Abc}}$ & $3.67 \pm 0.08^{\mathrm{Cb}}$ \\
\hline Margarida & $2.13 \pm 0.26^{\mathrm{Bb}}$ & $1.55 \pm 0.20^{\mathrm{Ba}}$ & $4.01 \pm 0.49^{\mathrm{Aa}}$ & $8.55 \pm 0.17^{\mathrm{Ba}}$ & $13.59 \pm 0.27^{\mathrm{Ac}}$ & $1.19 \pm 0.10^{\mathrm{Cd}}$ \\
\hline
\end{tabular}

Mean \pm standard deviation on dry basis. Different capital letters in the same line, for each parameter, correspond to the significant difference between different parts for the same cultivar $(\mathrm{P}<0.05)$ by Tukey's test. Different lowercase letters in the same column, for each parameter, correspond to significant difference of the same part for the different cultivars $(\mathrm{P}<0.05)$ by Tukey's test

\subsection{Fatty acids}

The major FA found in the three parts of the fruit were oleic acid (18:1n-9), palmitic acid (16:0), palmitoleic acid (16:1), linoleic acid (18:2n-6), and alpha-linolenic acid (18:3n-3) (Table 3), which is strictly essential FA, since it cannot be synthesized by humans (AGUIAR et al., 2011). The proportion of these components varied greatly according to the cultivar and the part of the fruit. The pulp showed the highest concentrations of FA. The peels and seeds also presented high concentrations of FA though they are considered byproducts.

Table 3. Fatty acids composition of different parts of four avocado cultivars

\begin{tabular}{|c|c|c|c|c|}
\hline \multirow[t]{2}{*}{ Fatty acids } & \multicolumn{4}{|c|}{ Pulp (mg/100 g) } \\
\hline & Hass & Quintal & Fortuna & Margarida \\
\hline $14: 0$ & $12.19 \pm 0.25^{b}$ & $13.75 \pm 0.46^{\mathrm{a}}$ & $10.56 \pm 0.17^{\mathrm{c}}$ & $11.85 \pm 0.18^{\mathrm{b}}$ \\
\hline $16: 0$ & $4398 \pm 14^{\mathrm{b}}$ & $5250 \pm 68^{\mathrm{a}}$ & $3713 \pm 96^{\mathrm{d}}$ & $3925 \pm 81^{\mathrm{c}}$ \\
\hline $16: 1$ & $2243 \pm 30^{\mathrm{a}}$ & $1134 \pm 21^{b}$ & $400.7 \pm 11.7^{\mathrm{d}}$ & $591.9 \pm 11.7^{\mathrm{c}}$ \\
\hline $17: 0$ & $2.200 \pm 0.030^{\mathrm{d}}$ & $6.240 \pm 0.180^{\mathrm{a}}$ & $4.610 \pm 0.120^{\mathrm{b}}$ & $3.870 \pm 0.110^{\mathrm{c}}$ \\
\hline $17: 1$ & $8.360 \pm 0.160^{\mathrm{c}}$ & $14.33 \pm 0.52^{\mathrm{a}}$ & $8.210 \pm 0.320^{\mathrm{c}}$ & $9.890 \pm 0.190^{b}$ \\
\hline $18: 0$ & $84.88 \pm 0.58^{\mathrm{d}}$ & $212.4 \pm 5.8^{\mathrm{a}}$ & $140.4 \pm 3.8^{\mathrm{b}}$ & $102.0 \pm 1.7^{\mathrm{c}}$ \\
\hline $18: \ln -9 \mathrm{c}$ & $4306 \pm 22^{d}$ & $10620 \pm 219^{\mathrm{a}}$ & $6695 \pm 191^{\mathrm{b}}$ & $6126 \pm 106^{\mathrm{c}}$ \\
\hline $18: 2 n-6 t$ & $4.750 \pm 0.48^{\mathrm{a}}$ & $2.74 \pm 0.32^{\mathrm{b}}$ & $1.210 \pm 0.070^{\mathrm{c}}$ & $2.690 \pm 0.480^{\mathrm{b}}$ \\
\hline $18: 2 n-6 c$ & $2237 \pm 19^{b}$ & $2318 \pm 41^{\mathrm{ab}}$ & $1781 \pm 54^{\mathrm{c}}$ & $2393 \pm 40^{\mathrm{a}}$ \\
\hline $20: 0$ & $9.68 \pm 0.19^{d}$ & $23.51 \pm 0.27^{\mathrm{a}}$ & $15.39 \pm 0.52^{b}$ & $11.59 \pm 0.18^{\mathrm{c}}$ \\
\hline $18: 3 n-3$ & $116.6 \pm 3.2^{\mathrm{d}}$ & $147.5 \pm 2.4^{b}$ & $134.0 \pm 4.8^{\mathrm{c}}$ & $147.5 \pm 4.4^{\mathrm{a}}$ \\
\hline $18: 3 n-6$ & ND & ND & ND & ND \\
\hline $20: 1$ & $24.97 \pm 12.45^{\mathrm{b}}$ & $71.73 \pm 1.85^{\mathrm{a}}$ & $30.45 \pm 1.11^{\mathrm{b}}$ & $29.86 \pm 0.65^{\mathrm{b}}$ \\
\hline $22: 0$ & $3.920 \pm 0.090^{\mathrm{d}}$ & $9.850 \pm 0.130^{\mathrm{a}}$ & $6.070 \pm 0.210^{\mathrm{b}}$ & $5.020 \pm 0.100^{\mathrm{c}}$ \\
\hline $22: 1$ & ND & ND & ND & ND \\
\hline
\end{tabular}

Acta Alimentaria 48, 2019 
Table 3. cont.

\begin{tabular}{lcccc}
\hline Fatty acids & Hass & Quintal & Pulp $(\mathrm{mg} / 100 \mathrm{~g})$ & \\
& $10.43 \pm 0.47^{\mathrm{b}}$ & $15.09 \pm 0.29^{\mathrm{a}}$ & $10.50 \pm 0.22^{\mathrm{b}}$ & $9.700 \pm 0.370^{\mathrm{b}}$ \\
\hline $24: 0$ & $14.28 \pm 0.05^{\mathrm{a}}$ & $0.3400 \pm 0.0500^{\mathrm{c}}$ & $5.230 \pm 0.030^{\mathrm{b}}$ & $0.2700 \pm 0.1700^{\mathrm{c}}$ \\
$22: 6 \mathrm{n}-3$ & $4519 \pm 15^{\mathrm{b}}$ & $5525 \pm 73^{\mathrm{a}}$ & $3896 \pm 101^{\mathrm{c}}$ & $4065 \pm 83^{\mathrm{c}}$ \\
$\Sigma$ SFA & $6583 \pm 52^{\mathrm{c}}$ & $11840 \pm 241^{\mathrm{a}}$ & $7135 \pm 204^{\mathrm{b}}$ & $6758 \pm 118^{\mathrm{bc}}$ \\
$\Sigma$ MUFA & $2373 \pm 16^{\mathrm{b}}$ & $2502 \pm 37^{\mathrm{ab}}$ & $1921 \pm 59^{\mathrm{c}}$ & $2564 \pm 42^{\mathrm{a}}$ \\
$\Sigma$ PUFA & $0.5300 \pm 0.0100^{\mathrm{b}}$ & $0.4000 \pm 0.0150^{\mathrm{d}}$ & $0.4900 \pm 0.0100^{\mathrm{c}}$ & $0.6300 \pm 0.0100^{\mathrm{a}}$ \\
PUFA/SFA & $17.14 \pm 0.56^{\mathrm{a}}$ & $15.92 \pm 0.30^{\mathrm{b}}$ & $12.80 \pm 0.05^{\mathrm{d}}$ & $14.29 \pm 0.37^{\mathrm{c}}$ \\
n-6/n-3 & & &
\end{tabular}

\begin{tabular}{lcccc}
\hline Fatty acids & Hass & \multicolumn{2}{c}{ Peel $(\mathrm{mg} / 100 \mathrm{~g})$} & \\
& $6.720 \pm 0.550^{\mathrm{b}}$ & $4.930 \pm 0.530^{\mathrm{c}}$ & $10.41 \pm 1.03^{\mathrm{a}}$ & $4.810 \pm 0.220^{\mathrm{c}}$ \\
\hline $14: 0$ & $1014 \pm 83^{\mathrm{b}}$ & $485.3 \pm 47.3^{\mathrm{c}}$ & $869.4 \pm 46.33^{\mathrm{b}}$ & $1344 \pm 63^{\mathrm{a}}$ \\
$16: 0$ & $450.9 \pm 44.2^{\mathrm{a}}$ & $81.40 \pm 6.16^{\mathrm{c}}$ & $78.21 \pm 10.85^{\mathrm{c}}$ & $159.7 \pm 7.5^{\mathrm{b}}$ \\
$16: 1$ & $\mathrm{ND}$ & $\mathrm{ND}$ & $\mathrm{ND}$ & ND \\
$17: 0$ & $11.72 \pm 1.63^{\mathrm{b}}$ & $13.71 \pm 11.26^{\mathrm{b}}$ & $39.50 \pm 5.59^{\mathrm{a}}$ & $34.13 \pm 1.60^{\mathrm{a}}$ \\
$17: 1$ & $25.97 \pm 3.68^{\mathrm{b}}$ & $31.50 \pm 7.09^{\mathrm{b}}$ & $55.01 \pm 3.53^{\mathrm{a}}$ & $44.05 \pm 2.07^{\mathrm{a}}$ \\
$18: 0$ & $1191 \pm 141^{\mathrm{b}}$ & $665.8 \pm 114.9^{\mathrm{c}}$ & $926.7 \pm 13.8^{\mathrm{bc}}$ & $2283 \pm 107^{\mathrm{a}}$ \\
$18: 1 \mathrm{n}-9 \mathrm{c}$ & $20.21 \pm 2.15^{\mathrm{b}}$ & $12.11 \pm 2.14^{\mathrm{c}}$ & $0.1100 \pm 0.0200^{\mathrm{d}}$ & $42.62 \pm 2.00^{\mathrm{a}}$ \\
$18: 2 \mathrm{n}-6 \mathrm{t}$ & $758.1 \pm 76.01^{\mathrm{a}}$ & $266.2 \pm 32.2^{\mathrm{c}}$ & $563.2 \pm 22.8^{\mathrm{b}}$ & $842.2 \pm 39.6^{\mathrm{a}}$ \\
$18: 2 \mathrm{n}-6 \mathrm{c}$ & $3.270 \pm 0.340^{\mathrm{c}}$ & $4.070 \pm 0.700^{\mathrm{bc}}$ & $6.740 \pm 0.390^{\mathrm{a}}$ & $5.180 \pm 0.240^{\mathrm{b}}$ \\
$20: 0$ & $132.5 \pm 29.0^{\mathrm{a}}$ & $57.03 \pm 7.57^{\mathrm{b}}$ & $123.6 \pm 8.3^{\mathrm{a}}$ & $108.7 \pm 5.1^{\mathrm{a}}$ \\
$18: 3 \mathrm{n}-3$ & $\mathrm{ND}$ & $\mathrm{ND}$ & $\mathrm{ND}$ & $N \mathrm{ND}$ \\
$18: 3 \mathrm{n}-6$ & $5.550 \pm 2.670^{\mathrm{ab}}$ & $6.740 \pm 1.580^{\mathrm{ab}}$ & $3.650 \pm 0.530^{\mathrm{b}}$ & $7.920 \pm 0.370^{\mathrm{a}}$ \\
$20: 1$ & $3.630 \pm 0.360^{\mathrm{b}}$ & $4.520 \pm 0.590^{\mathrm{b}}$ & $8.780 \pm 1.060^{\mathrm{a}}$ & $3.070 \pm 0.140^{\mathrm{b}}$ \\
$22: 0$ & $\mathrm{ND}$ & $\mathrm{ND}$ & $N \mathrm{ND}$ & $N \mathrm{ND}$ \\
$22: 1$ & $7.600 \pm 0.640^{\mathrm{b}}$ & $6.150 \pm 0.600^{\mathrm{b}}$ & $12.83 \pm 1.76^{\mathrm{a}}$ & $5.520 \pm 0.250^{\mathrm{b}}$ \\
$24: 0$ & $0.1900 \pm 0.0600^{\mathrm{a}}$ & $0.3700 \pm 0.1700^{\mathrm{a}}$ & $0.2600 \pm 0.2300^{\mathrm{a}}$ & $0.04000 \pm 0.01000^{\mathrm{a}}$ \\
$22: 6 \mathrm{n}-3$ & $1061 \pm 88^{\mathrm{b}}$ & $536.5 \pm 56.53^{\mathrm{c}}$ & $963.1 \pm 53.1^{\mathrm{b}}$ & $1407 \pm 66^{\mathrm{a}}$ \\
$\Sigma$ SFA & $1659 \pm 179^{\mathrm{b}}$ & $767.7 \pm 112.1^{\mathrm{c}}$ & $1048 \pm 29^{\mathrm{c}}$ & $2485 \pm 117^{\mathrm{a}}$ \\
$\Sigma$ MUFA & $911.0 \pm 106.8^{\mathrm{a}}$ & $335.7 \pm 41.6^{\mathrm{c}}$ & $687.1 \pm 31.2^{\mathrm{b}}$ & $993.5 \pm 46.8^{\mathrm{a}}$ \\
$\Sigma$ PUFA & $0.8600 \pm 0.0300^{\mathrm{a}}$ & $0.6200 \pm 0.0100^{\mathrm{c}}$ & $0.7100 \pm 0.0100^{\mathrm{b}}$ & $0.7100 \pm 0.0000^{\mathrm{b}}$ \\
PUFA/SFA & $4.850 \pm 0.160^{\mathrm{c}}$ & $4.550 \pm 0.130^{\mathrm{c}}$ & $8.140 \pm 0.000^{\mathrm{a}}$ \\
$\mathrm{n}-6 / \mathrm{n}-3$ & $5.960 \pm 0.650^{\mathrm{b}}$ & & &
\end{tabular}

\begin{tabular}{lcccc}
\hline Fatty acids & \multicolumn{4}{c}{ Seed $(\mathrm{mg} / 100 \mathrm{~g})$} \\
& Hass & Quintal & Fortuna & Margarida \\
\hline $14: 0$ & $2.180 \pm 0.100^{\mathrm{b}}$ & $4.440 \pm 1.370^{\mathrm{a}}$ & $2.520 \pm 0.100^{\mathrm{b}}$ & $1.430 \pm 0.120^{\mathrm{b}}$ \\
$16: 0$ & $75.17 \pm 2.14^{\mathrm{b}}$ & $153.1 \pm 23.3^{\mathrm{a}}$ & $145.7 \pm 8.9^{\mathrm{a}}$ & $61.03 \pm 3.96^{\mathrm{b}}$ \\
$16: 1$ & $11.35 \pm 0.54^{\mathrm{a}}$ & $12.78 \pm 3.16^{\mathrm{a}}$ & $11.14 \pm 0.83^{\mathrm{a}}$ & $4.870 \pm 0.500^{\mathrm{b}}$ \\
$17: 0$ & $\mathrm{ND}$ & $\mathrm{ND}$ & $\mathrm{ND}$ & ND \\
$17: 1$ & $\mathrm{ND}$ & $\mathrm{ND}$ & $\mathrm{ND}$ & ND \\
$18: 0$ & $2.910 \pm 0.150^{\mathrm{b}}$ & $12.31 \pm 3.93^{\mathrm{a}}$ & $5.030 \pm 0.140^{\mathrm{b}}$ & $5.100 \pm 0.100^{\mathrm{b}}$ \\
$18: 1 \mathrm{ln}-9 \mathrm{c}$ & $36.45 \pm 1.20^{\mathrm{b}}$ & $135.8 \pm 13.8^{\mathrm{a}}$ & $116.3 \pm 7.6^{\mathrm{a}}$ & $43.12 \pm 2.44^{\mathrm{b}}$
\end{tabular}


Table 3. cont.

\begin{tabular}{|c|c|c|c|c|}
\hline \multirow[t]{2}{*}{ Fatty acids } & \multicolumn{4}{|c|}{ Seed $(\mathrm{mg} / 100 \mathrm{~g})$} \\
\hline & Hass & Quintal & Fortuna & Margarida \\
\hline $18: 2 n-6 t$ & $0.3500 \pm 0.0000^{\mathrm{b}}$ & $2.700 \pm 0.700^{\mathrm{a}}$ & $2.030 \pm 0.110^{\mathrm{a}}$ & $0.7500 \pm 0.01000^{\mathrm{b}}$ \\
\hline $18: 2 n-6 c$ & $102.6 \pm 3.2^{c}$ & $277.2 \pm 18.9^{\mathrm{a}}$ & $204.0 \pm 13.0^{\mathrm{b}}$ & $103.7 \pm 7.8^{\mathrm{c}}$ \\
\hline $20: 0$ & ND & ND & ND & ND \\
\hline $18: 3 n-3$ & $10.21 \pm 0.28^{\mathrm{c}}$ & $78.30 \pm 7.41^{\mathrm{a}}$ & $20.40 \pm 1.56^{\mathrm{b}}$ & $13.74 \pm 0.83^{b c}$ \\
\hline $18: 3 n-6$ & $0.8200 \pm 0.0500^{\mathrm{c}}$ & $6.620 \pm 0.120^{\mathrm{a}}$ & $2.180 \pm 0.100^{\mathrm{b}}$ & $0.3100 \pm 0.0300^{\mathrm{d}}$ \\
\hline $20: 1$ & $4.170 \pm 0.0300^{\mathrm{c}}$ & $28.92 \pm 2.82^{\mathrm{a}}$ & $10.66 \pm 0.42^{b}$ & $4.610 \pm 1.390^{\mathrm{c}}$ \\
\hline $22: 0$ & $2.020 \pm 0.170^{\mathrm{c}}$ & $5.750 \pm 0.210^{\mathrm{a}}$ & $3.910 \pm 0.360^{\mathrm{b}}$ & $2.500 \pm 0.070^{\mathrm{c}}$ \\
\hline $22: 1$ & $0.2100 \pm 0.0400^{\mathrm{c}}$ & $14.80 \pm 0.30^{\mathrm{a}}$ & $1.010 \pm 0.060^{\mathrm{b}}$ & $0.1500 \pm 0.0600^{\mathrm{c}}$ \\
\hline $24: 0$ & $2.970 \pm 0.320^{\mathrm{c}}$ & $10.21 \pm 0.59^{\mathrm{a}}$ & $7.670 \pm 0.560^{\mathrm{b}}$ & $3.370 \pm 0.110^{\mathrm{c}}$ \\
\hline $22: 6 n-3$ & $0.1000 \pm 0.0200^{\mathrm{b}}$ & $0.1700 \pm 0.0100^{\mathrm{ab}}$ & $0.2100 \pm 0.0400^{\mathrm{a}}$ & $0.1400 \pm 0.0600^{\mathrm{ab}}$ \\
\hline$\Sigma$ SFA & $85.26 \pm 2.87^{\mathrm{b}}$ & $185.8 \pm 20.2^{\mathrm{a}}$ & $164.8 \pm 10.0^{\mathrm{a}}$ & $73.44 \pm 4.14^{\mathrm{b}}$ \\
\hline$\Sigma$ MUFA & $52.18 \pm 0.82^{\mathrm{c}}$ & $192.3 \pm 15.2^{\mathrm{a}}$ & $139.1 \pm 8.8^{\mathrm{b}}$ & $52.75 \pm 4.37^{\mathrm{c}}$ \\
\hline$\Sigma$ PUFA & $114.1 \pm 3.5^{\mathrm{c}}$ & $364.9 \pm 17.5^{\mathrm{a}}$ & $228.8 \pm 14.7^{\mathrm{b}}$ & $118.6 \pm 7.1^{\mathrm{c}}$ \\
\hline PUFA/SFA & $1.340 \pm 0.020^{\mathrm{b}}$ & $1.990 \pm 0.320^{\mathrm{ab}}$ & $1.390 \pm 0.010^{\mathrm{b}}$ & $1.620 \pm 0.010^{\mathrm{ab}}$ \\
\hline$n-6 / n-3$ & $10.06 \pm 0.01^{\mathrm{a}}$ & $3.680 \pm 0.480^{\mathrm{c}}$ & $10.11 \pm 0.17^{\mathrm{a}}$ & $7.580 \pm 0.940^{\mathrm{b}}$ \\
\hline
\end{tabular}

Mean \pm standard deviation. Different letters in the same line, for each part of the fruit, correspond to significant difference $(\mathrm{P}<0.05)$ by Tukey's's test. Comparisons were made between the same parts of the different cultivars of avocado. PUFA: polyunsaturated fatty acids; MUFA: monounsaturated fatty acids; SFA: saturated fatty acids; n-6: omega-6 fatty acid; n-3: omega-3 fatty acid; ND: not determined

In the pulps of Quintal, Fortuna, and Margarida cultivars, oleic acid was the main fatty acid, however, in Hass cultivar the fatty acid that appeared in a higher proportion was palmitic acid. The peel of Quintal cultivar presented lower amounts of saturated fatty acids (SFA) and polyunsaturated fatty acids (PUFA) than the peel of Margarida, Fortuna, and Hass cultivars, with significant differences. The content of monounsaturated fatty acids (MUFA) was the highest in the pulp and peels for all cultivars followed by SFA and PUFA in a lower proportion. These results are in agreement with those reported by other authors for Hass avocado pulp (Ozdemir \& Topuz, 2004; Vekiari et al., 2004; Meyer \& Terry, 2008).

DonetTI and Terry (2014) carried out a study on Hass avocado pulp oil from Chile, Peru, and Spain, in which oleic acid was the main fatty acid in all samples analysed, with a mean content of $53 \%$, followed by palmitic acid (20\%), linoleic acid (14\%), palmitoleic acid $(7 \%)$, and alpha-linolenic acid (4\%). These results were similar to those found in the present study for Hass avocado pulp, with $32.6 \%$ for oleic acid, $31.7 \%$ for palmitic acid, $16.6 \%$ for linoleic acid, $16.3 \%$ for palmitoleic acid, and $0.9 \%$ for alpha-linolenic acid.

Alpha-linolenic content, an omega-3 FA, was higher for Quintal and Margarida pulps, followed by Fortuna, with concentrations higher than for Hass pulp. Considering that Hass avocado presented the lowest amount of pulp (57.6\%) with regard to the other cultivars (74.7-81.0\%), Quintal, Fortuna, and Margarida are better sources of this FA than Hass avocado. In addition, Quintal pulp presented higher values of lipid content than the other three cultivars studied. Hass and Fortuna peels presented similar concentrations to those of the pulps, which make them a good source of omega-3 fatty acids. 


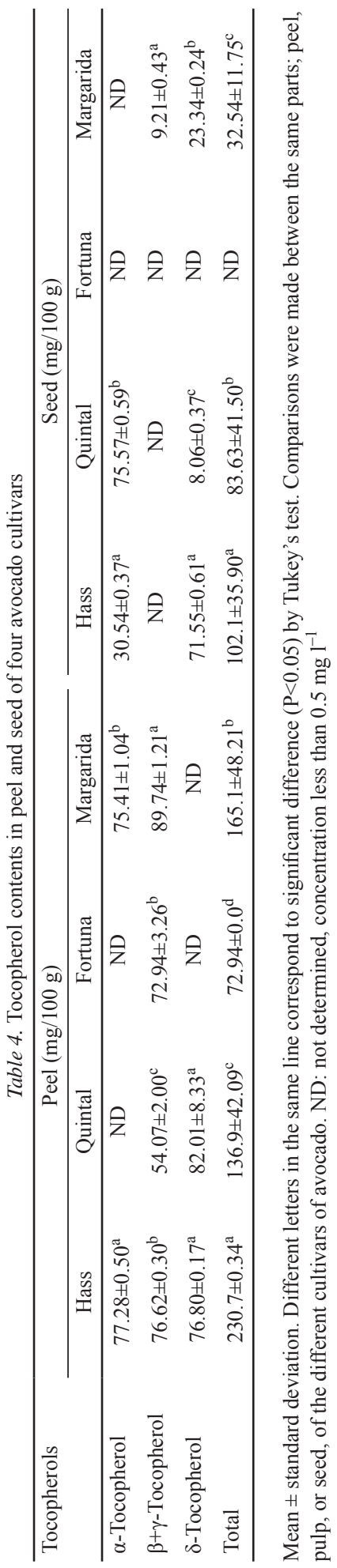


There were significant variations $(\mathrm{P}<0.05)$ between the PUFA/SFA ratios with $0.5-0.6$ for pulps, $0.6-0.9$ for peels, and 1.3-2.0 for seeds. Values lower than 0.45 are considered undesirable, because they may increase blood cholesterol (Department Of Health UK, 1994). Therefore, it can be stated that the peels and seeds of the studied cultivars presented desirable values for PUFA/SFA ratios, because they are above 0.45 , higher than the values found for the pulps.

The World Health Organization (WHO, 1995) suggests that the balance between dietary omega-6/omega-3 PUFA should be between 5:1 and 10:1. The peels of all avocado cultivars and the seeds of Quintal and Margarida cultivars showed values in accordance with this recommendation, and all pulps analysed presented higher values.

\subsection{Tocopherol content}

The presence of tocopherol isomers in the avocado pulps was not detected at the concentration of the standard calibration curve used (Table 4).

The concentration of total vitamin $\mathrm{E}$ isomers analysed (alpha, beta, gamma, and delta tocopherol) differed statistically $(\mathrm{P}<0.05)$ in the cultivars. It was also possible to verify that the peels of avocados showed higher values (72.9-230.7 mg/100 g) than the seeds. Hass cultivar showed the highest sum of the total tocopherols $(230.7 \mathrm{mg} / 100 \mathrm{~g})$ when compared to the other cultivars, with $\alpha$-tocopherol being predominant $(77.3 \mathrm{mg} / 100 \mathrm{~g}$ ) for this cultivar. Peels of Quintal and Fortuna cultivars did not present $\alpha$-tocopherol. Other examples of oils with $\alpha$-tocopherol as the predominant isomer are: sunflower $\left(403-935 \mathrm{mg} \mathrm{kg}^{-1}\right)$, palm (30$280 \mathrm{mg} \mathrm{kg}^{-1}$ ), and grape (16-38 $\mathrm{mg} \mathrm{kg}^{-1}$ ) (Codex Alimentarius Commission, 2009).

\section{Conclusions}

The four avocado cultivars analysed showed high lipid contents, making them good sources of edible vegetable oil. Avocado pulps showed high concentrations of MUFA, especially oleic acid, with emphasis on the pulp of Quintal cultivar. Quintal, Fortuna, and Margarida pulps presented higher values of alpha-linolenic FA than Hass pulp. In addition, the peel of all avocado cultivars and seeds of Quintal and Margarida presented lower omega-6/omega-3 ratios. There was also a considerable amount of tocopherols in the peel and seeds. Hass peel showed the highest values.

According to the results obtained, the peel and seeds of avocado are byproducts that can be utilized in the food industry.

We acknowledge CAPES - Coordination for the Improvement of High Education Personnel for the financial support.

\section{References}

Aguiar, A.C., Cottica, S.M., Boroski, M., Oliveira, C.C., Bonafe, E.G., Franca, P.B., Souza, N.E. \& Visentainer, J.V. (2011): Quantification of essential fatty acids in the heads of Nile tilapia (Oreochromis niloticus) fed with linseed oil. J. Brazil. Chem. Soc., 22, 643-647.

AOAC (1998): Official methods of analysis of AOAC International, Association of Official Analytical Chemists (16th ed), Moisture in malt (935.29), Ash (900.02), Total Kjeldahl nitrogen (920.152). 
Bligh, E.G. \& Dyer, W.J. (1959): A rapid method of total lipid extraction and purification. Can. J. Biochem. Phys., 37, 911-917.

Codex Alimentarius Commission (2009): Codex-Stan 210: Codex standard for named vegetable oils. Rome.

Department of HeAlth (UK) (1994): Nutritional aspects of cardiovascular disease: Report on health and social subjects. No.46, H.M.S.O., London. 186 pages.

DonetTi, M. \& Terry, L.A. (2014): Biochemical markers defining growing area and ripening stage of imported avocado fruit cv. Hass. J. Food Compos. Anal., 34, 90-98.

Duarte, P.F., Chaves, M.A., Borges, C.D., Mendonça, C.R.B. (2016): Avocado: characteristics, health benefits and uses. Cienc. Rural, 46, 747-754.

Freitas, L.S., Jacques, R.A., Richter, M.F., Silva, A.L. \& Caramão, E.B. (2008): Pressurized liquid extraction of vitamin E from Brazilian grape seed oil. J. Chromatogr. A., 1200, 80-83.

GómEz-López, V.M. (1998): Characterization of avocado (Persea americana Mill.) varieties of very low oil content. J. Agr. Food Chem., 46, 3643-3647.

GómEz-López, V.M. (2002): Fruit characterization of high oil content avocado varieties. Sci. Agr., 59, 403-406.

Hartman, L. \& Lago, R.C.A. (1973): Rapid preparation of fatty acid methyl esters from lipids. Lab. Pract., 22, 474-476.

Honarbakhsh, S. \& Schachter, M.W. (2009): Vitamins and cardiovascular disease. Brit. J. Nutr., 101, 1113-1131.

MeYer, M.D. \& TERRY, L.A. (2008): Development of a rapid method for the sequential extraction and subsequent quantification of fatty acids and sugars from avocado mesocarp tissue. J. Agr. Food Chem., 56, 7439-7445.

OzDemir, F. \& Topuz, A. (2004): Changes in dry matter, oil content and fatty acids composition of avocado during harvesting time and post-harvesting ripening period. Food Chem., 86, 79-83.

R Core Team (2016): R: A language and environment for statistical computing. R Foundation for Statistical Computing, Vienna, Austria. https://www.R-project.org/

Tango, J.S., Carvalho, C.R.L. \& Soares, N.B. (2004): Caracterização física e química de frutos de abacate visando a seu potencial para extração de óleo (Physical and chemical characterization of avocado fruit aiming at their potential for oil extraction). Rev. Bras. Frutic., 26, 17-23.

Vekiari, S.A., Papadopoulou, P.P., Lionakis, S. \& Krystallis, A. (2004): Variation in the composition of Cretan avocado cultivars during ripening. J. Sci. Food Agr., 84, 485-492.

Villa-Rodríguez, J.A., Molina-Corral, F.J., Ayala-Zavala, J.F., Olivas, G.I. \& González-Aguilar, G.A. (2011): Effect of maturity stage on the content of fatty acids and antioxidant activity of 'Hass' avocado. Food Res. Int., 44, 1231-1237.

Vinha, A.F., Moreira, J. \& Barreira, S.V.P. (2013): Physicochemical parameters, phytochemical composition and antioxidant activity of the algarvian avocado (Persea americana Mill.). J. Agr. Sci., 5(12), 100-109.

VisentaINER, J.V. (2012): Aspectos analíticos da resposta do detector de ionização em chama para ésteres de ácidos graxos em biodiesel e alimentos (Analytical aspects of the flame ionization detector response of fatty acid esters in biodiesels and foods). Quim. Nova, 35, 274-279.

WHO (1995): World Health Organization Joint consultation: Fats and oils in human nutrition. Nutr. Rev., 53, 202205. 